\title{
MORPHOLOGICAL VARIABILITY \\ OF THE CALTHA PALUSTRIS L. COMPLEX (RANUNCULACEAE) IN POLAND
}

\author{
ELŻBIETA CIEŚLAK \\ W. Szafer Institute of Botany, Polish Academy of Sciences \\ Lubicz 46, 31-512 Kraków, Poland \\ e-mail: cieslak@ib-pan.krakow.pl
}

(Received: April 22, 2003. Accepted: October 10, 2003)

\begin{abstract}
The paper presents results of biosystematic analysis of the critical group of Caltha palustris L. based on 71 populations from Poland. After a preliminary statistical analysis, fourteen morphological characters (nine quantitative and five qualitative), describing size and shape of basal leaves and mature follicles as well as stem morphology, were selected for the clearest differentiation of the complex. Several groups of morphotypes were distinguished within the complex, based on the statistical analysis of this group of characters. Against this background the taxonomy of the complex is proposed. Two species - Caltha laeta Schott, Nyman and Kotschy and Caltha palustris L. - and three subspecies within C. palustris (C. p. subsp. palustris, C. p. subsp. cornuta (Schott, Nyman and Kotschy) Hegi and C. p. subsp. radicans (T.F. Forst.) Syme, were distinguished in Poland. The status of the taxa within the Polish flora is defined. The paper includes also a key for determination of the complex taxa, as well as their detailed descriptions.
\end{abstract}

KEY WORDS: Caltha palustris, C. p. subsp. palustris, C. p. subsp. cornuta, C. p. subsp. radicans, Caltha laeta, taxonomy, morphological variability, statistics, systematic key, Poland.

\section{INTRODUCTION}

The genus Caltha (Ranunculaceae) includes approx. 40 species, among which there are several widely defined critical taxa. The Linnean Caltha palustris, the unique representative of the genus in Europe, is a species with a very large, circumboreal distribution (Meusel et al. 1965; Hultèn 1970; Hultèn and Fries 1986). Because of its large morphological variability, the complex has been for a long time a subject of taxonomical revisions (which were concentrated mainly on morphological characters), resulting in different conclusions. H. Schott, C.F. Nyman and Th. Kotschy (1854) divided the Linnean taxon Caltha palustris into 6 narrowly defined species: $C$. cornuta, $C$. latifolia, $C$. laeta, $C$. intermedia, $C$. vulgaris and $C$. alpestris. Another author, G. Beck (1886) decided to keep three of them at the species level: $C$. palustris (formerly $C$. vulgaris), $C$. laeta and $C$. cornuta, while the remaining three taxa were considered as varieties: $C$. latifolia within $C$. cornuta, $C$. alpestris within $C$. laeta, and $C$. intermedia as var. typica within $C$. palustris. A morphotype characterized by a creeping stem was described for the first time from Scotland by T.F. Forster (1807) as C. radicans, presented afterwards by E. Fries (1846) as a variety within $C$. palustris, while J.T. Syme (1863) treated it as a subspecies. F. Pursh (1813) de- scribed an American morphotype characterized by a creeping stem as $C$. flabellifolia.

Graebner (1929), in his monograph of the genus Caltha, considered the whole complex as one species with several lower-rank taxa. In more recent European works (Hegi 1912; Soó and Kovács-Láng 1964; Zimmermann 1965; Wcisło 1968; Woodell and Kootin-Sanwu 1971; Werpachowski 1998; Chrtková and Jarolimová 1999; Hrouda 2002; Stohr 2002), in which different groups of characters (micromorphology, karyology, biochemistry) were considered, the authors returned to the Linnean conception of C. palustris, but distinguished several lower-rank units within this complex. The wide Linnean conception of the complex was applied by the authors of both editions of the Flora Europaea (Tutin et al. 1964; Akeroyd 1993).

The range of variability and intraspecific division of widely defined $C$. palustris L. in Poland has not been clearly determined so far. Zapałowicz (1908), following the decisions of Schott, Nyman and Kotschy, adopted the narrow definition of taxa and distinguished within C. palustris L. and $C$. laeta Schott, Nyman and Kotschy, several additional varieties and forms: C. palustris L. var. subcornuta for. zawojensis Zap., C. laeta Schott, Nyman and Kotschy var. czarnohorensis Zap. and var. pseudocornuta Zap. Paczoski (1927) and Szafer et al. (1953) adopted, after Schott et al. 
(1854), the division of the complex into three species: $C$. palustris, C. cornuta, C. laeta. Pawłowski (1956) distinguished two species, namely: $C$. palustris L. and $C$. laeta Schott, Nyman and Kotschy; within $C$. palustris L. he defined two subspecies: subsp. palustris and subsp. cornuta (Schott, Nyman and Kotschy) Hegi, and within C. laeta three varieties: var. laeta, var. alpestris (Schott, Nyman and Kotschy) Beck and var. rostrata Borb. Kucowa (1985) also divided the complex into two species. Mirek et al. (1995) adopted the division of $C$. palustris L. into three subspecies: subsp. laeta (Schott, Nyman and Kotschy) Hegi, subsp. palustris and subsp. cornuta (Schott, Nyman and Kotschy) Hegi.

The cytological and karyological (Skalińska et al. 1959; Wcisło 1964, 1967, 1968; Cieślak et al. 2000), as well as ecological research (Falińska 1974, 1976, 1981, 1998; Werpachowski 1989, 1998), do not allow to formulate unequivocal statements concerning the status of the taxa of $C$. $p a$ lustris complex in Poland.

No morphological studies on this complex as a whole have been carried out in Poland. The currently applied systematics and nomenclature is based on these by Mirek et al. (1995). The present work's aim is to analyse in detail the variability of Caltha palustris complex in respect to different groups of characters, distinguishing and characterising the taxa within the complex and determining the range, position and nomenclature of the taxa present in Poland.

\section{MATERIAL AND METHODS}

\section{Plant material}

The plant material was collected from the whole territory of Poland in the years 1996-1999. The sampling of populations was done within homogeneous phytocoenose patches, usually not exceeding 100-200 $\mathrm{m}^{2}$ (Table 1). In total, 71 population samples of 21 to 42 individuals each were analysed.

For biometric studies, two mature basal leaves and stem with follicles were chosen randomly from each individual. The attention was paid to choosing the basal leaves at an appropriate developmental stage and follicles that were mature, but not yet broken. Measurements were performed on dried material; in total 2075 individuals were examined. In the numerical analyses individuals were regarded as operational taxonomic units (OTUs). Voucher specimens from all populations were deposited at the herbarium of the W. Szafer Institute of Botany, Polish Academy of Sciences, in Cracow - KRAM.

In case of metric (interval) characters, if more than one measure per individual was taken (e.g. in case of 2 basal leaves and follicles), mean values were calculated for each individual. Qualitative multistate data, coded in the binary way (0-1) were summed up in their respective states. Before analyses all morphological data were normalized, and these had a normal or log-normal distribution.

\section{Statistical analyses}

The characters were chosen on the basis of the correlation coefficient values, loading values obtained in Principal Component Analysis (PCA) and in Correspondence Analysis $(\mathrm{CA})$ - in both methods based on first 3 axes. These values were confirmed by the Wilks' lambda values and discriminant power obtained in Discriminate Analysis (DA). The author used also one way analyses of variance (ANOVA) to compare the morphological characters among populations and taxa.

Classification and phenetic relationships between OTUs and described morphological relationships among taxa were established on the basis of cluster analysis, PCA and CA. The DA classification matrix was used to evaluate the correctness of a priori distribution of OTUs within respective taxa. The Mantel Test was used to verify the hypothesis of lack of dependence between the matrix of morphological characters and the matrix of geographical distribution of the sampled populations. The data analyses were performed using the StatSoft Statistica software version 5.97.

The following values were calculated for respective characters and taxa: arithmetic mean value $(X)$, standard deviation (SD), standard error (SE), minimal (Min) and maximal (Max) values; they are presented in the Table 2.

\section{RESULTS}

\section{Morphological characters and their statistical analysis}

In the first step, the PCA was performed on all quantitative and ratio characters. Initially, 48 characters were scored and 26 ratios were derived from these basic characters. On the basis of cumulative variance and loading values of characters for the first three principal component axes, nine characters were chosen for subsequent analysis (Table 3). The selected features provided the greatest contribution to differentiation among morphological groups and explained the existing variability in the highest percentage (independently of taxonomic classification). The three component axes explain $74 \%$ of the total variance properly: the first and the second components explain $28 \%$ of the variation each, the third one $-18 \%$. The highest loading value for the first principal component was for AF, DD and RF; for the second principal component - WL, RL40 and RL80; for the third principal component - DL, RL140 and AS (which has an opposite correlation to previous characters see Table 4 and Fig. 1a).

The values of $\mathrm{F}$ statistics obtained in ANOVA for nine characters were higher than the critical $\mathrm{F}$ value $\left(\mathrm{F}_{0.05 ; 3 ; \infty}=\right.$ 2.60) and indicated significant differences between the taxa (Table 4).

The qualitative characters have been separately analyzed using CA; basing on this method, five characters (17 states) were selected providing the best differentiation and description of variability within morphological groups. The cumulative percentage of the variance for the first three axes is $40 \%$. The following qualitative characters had the highest loading values for the first axis: stem morphology (state a), margin of lobes (state c), the top of the basal leaf (state d) and divergence of follicles (states a and d). For the second axis they were: characters describing shape of beak follicles (state d), divergence of follicles (state d) and characters describing the margin of the top of basal leaves (state a). The graphical presentation of validity for particular features with their states obtained from this analysis is presented in Fig. 1b.

The analysed taxa differ significantly in respect to the entire set of characters. The characters that discriminate in the clearest way the groups within the complex are: form 
TABLE 1. Location of sample populations of Caltha palustris complex in Poland. $\mathrm{N}$ - number of individuals, $\mathrm{CL}$ - classification of individuals: $\mathrm{P}-\mathrm{C}$. palustris subsp. palustris, $\mathrm{C}-$ C. palustris subsp. cornuta, $\mathrm{R}-$ C. palustris subsp. radicans, $\mathrm{L}-$ C. laeta.

\begin{tabular}{|c|c|c|c|c|c|}
\hline \multirow[b]{2}{*}{1} & \multirow{2}{*}{$\begin{array}{l}\text { Locality and habitat } \\
\text { Mrzeżyno, in a moist meadow, at the Rega riverside }\end{array}$} & \multicolumn{2}{|c|}{ Coordinates of the locality } & \multirow{2}{*}{$\mathrm{N}$} & \multirow{2}{*}{$\begin{array}{l}\mathrm{CL} \\
\mathrm{P}\end{array}$} \\
\hline & & $\mathrm{N} 54^{\circ} 08^{\prime}$ & E $15^{\circ} 17^{\prime}$ & & \\
\hline 2 & Brodniki, in a moist meadow & N $53^{\circ} 53^{\prime}$ & E $15^{\circ} 12^{\prime}$ & 29 & $\mathrm{P}$ \\
\hline 3 & Mścice, in a moist meadow, among rushes & $\mathrm{N} 54^{\circ} 13^{\prime}$ & E $16^{\circ} 05^{\prime}$ & 25 & $\mathrm{P}$ \\
\hline 4 & Duninowo, in a moist meadow & $\mathrm{N} 54^{\circ} 32^{\prime}$ & E $16^{\circ} 49^{\prime}$ & 30 & $\mathrm{P}$ \\
\hline 5 & Gdynia-Wielki Kack, in an alder-bog forest, at a stream & N $54^{\circ} 32$ & E $18^{\circ} 32^{\prime}$ & 30 & $\mathrm{P}$ \\
\hline 6 & Bartoszyce, in a stream & $\mathrm{N} 54^{\circ} 15^{\prime}$ & E $20^{\circ} 47^{\prime}$ & 29 & $\mathrm{P}, \mathrm{C}$ \\
\hline 7 & Dubeninki, in an alder forest & $\mathrm{N} 54^{\circ} 17^{\prime}$ & E $22^{\circ} 37^{\prime}$ & 28 & $\mathrm{R}$ \\
\hline 8 & Frącki, in an alder forest, at a stream & $\mathrm{N} 54^{\circ} 00^{\prime}$ & E $23^{\circ} 20^{\prime}$ & 29 & $\mathrm{P}, \mathrm{R}$ \\
\hline 9 & Trzcianka, in a dry drainage ditch & N $53^{\circ} 28^{\prime}$ & E $23^{\circ} 22^{\prime}$ & 28 & $\mathrm{R}$ \\
\hline 10 & Goniadz, in a fen at the Biebrza riverside & N $53^{\circ} 29^{\prime}$ & E $22^{\circ} 44^{\prime}$ & 28 & $\mathrm{P}$ \\
\hline 11 & Mikołajki, in a ditch and in an alder forest & N $53^{\circ} 48^{\prime}$ & E $21^{\circ} 35^{\prime}$ & 30 & $\mathrm{P}$ \\
\hline 12 & Olsztyn Gutkowo, in a moist meadow, at a lakeside & $\mathrm{N} 53^{\circ} 48^{\prime}$ & E $20^{\circ} 23^{\prime}$ & 28 & $\mathrm{R}$ \\
\hline 13 & Prabuty, at the jezioro Grazymowskie, a lakeside & N $53^{\circ} 43^{\prime}$ & E $19^{\circ} 11^{\prime}$ & 30 & $\mathrm{P}, \mathrm{R}$ \\
\hline 14 & Gołubie Kaszubskie, at the Jezioro Patulskie, a lakeside & $\mathrm{N} 54^{\circ} 13^{\prime}$ & E $18^{\circ} 02^{\prime}$ & 29 & $\mathrm{R}$ \\
\hline 15 & Lubiki, in a ditch (in water) & $\mathrm{N} 53^{\circ} 51^{\prime}$ & E $18^{\circ} 08^{\prime}$ & 20 & $\mathrm{R}$ \\
\hline 16 & Czaplinek, at the Jezioro Czaplino, a lakeside & N $53^{\circ} 34^{\prime}$ & E $16^{\circ} 15^{\prime}$ & 30 & $\mathrm{R}$ \\
\hline 17 & Sulibórz, in a moist meadow & $\mathrm{N} 53^{\circ} 20^{\prime}$ & E $15^{\circ} 35^{\prime}$ & 27 & $\mathrm{P}, \mathrm{R}$ \\
\hline 18 & Szwadzin, in a moist meadow & $\mathrm{N} 53^{\circ} 00^{\prime}$ & E $15^{\circ} 05^{\prime}$ & 30 & $\mathrm{P}$ \\
\hline 19 & Buszków, in an alder forest & $\mathrm{N} 53^{\circ} 21^{\prime}$ & E $17^{\circ} 52^{\prime}$ & 30 & $\mathrm{P}, \mathrm{R}$ \\
\hline 20 & Kurzętnik, in a moist meadow and in an alder forest & N $53^{\circ} 24^{\prime}$ & E $19^{\circ} 35^{\prime}$ & 30 & $\mathrm{P}, \mathrm{R}$ \\
\hline 21 & Zbójno, in a moist meadow & N $52^{\circ} 59^{\prime}$ & E $19^{\circ} 07^{\prime}$ & 29 & $\mathrm{P}$ \\
\hline 22 & Płock, in a moist meadow & $\mathrm{N} 52^{\circ} 33^{\prime}$ & E $19^{\circ} 42^{\prime}$ & 30 & $\mathrm{P}, \mathrm{R}$ \\
\hline 23 & Ciechanów, in an alder forest & $\mathrm{N} 52^{\circ} 52^{\prime}$ & E $20^{\circ} 28^{\prime}$ & 29 & $\mathrm{R}$ \\
\hline 24 & Sypniewo, in a moist meadow & $\mathrm{N} 53^{\circ} 01^{\prime}$ & E $21^{\circ} 18^{\prime}$ & 29 & $\mathrm{R}$ \\
\hline 25 & Ostrów Mazowiecki, in a ditch (in water) & N $52^{\circ} 48^{\prime}$ & E $21^{\circ} 53^{\prime}$ & 28 & $\mathrm{P}, \mathrm{R}$ \\
\hline 26 & Łochów, in a moist meadow & $\mathrm{N} 52^{\circ} 32^{\prime}$ & E $21^{\circ} 42^{\prime}$ & 30 & $\mathrm{P}$ \\
\hline 27 & Morze, in a ditch, in water & $\mathrm{N} 52^{\circ} 43^{\prime}$ & E $23^{\circ} 24^{\prime}$ & 28 & $\mathrm{P}, \mathrm{R}$ \\
\hline 28 & Zalesie Moszczona, in an alder forest & $\mathrm{N} 52^{\circ} 27^{\prime}$ & E $23^{\circ} 01^{\prime}$ & 30 & $\mathrm{R}$ \\
\hline 29 & Włodawa, in a moist meadow & $\mathrm{N} 51^{\circ} 33^{\prime}$ & E $23^{\circ} 33^{\prime}$ & 30 & $\mathrm{P}, \mathrm{C}$ \\
\hline 30 & Chełm, in a moist meadow & $\mathrm{N} 51^{\circ} 08^{\prime}$ & E $23^{\circ} 29^{\prime}$ & 30 & $\mathrm{P}$ \\
\hline 31 & Hrubieszów, in a moist meadow & N $50^{\circ} 48^{\prime}$ & E $23^{\circ} 53^{\prime}$ & 30 & $\mathrm{P}, \mathrm{C}$ \\
\hline 32 & Mchy, in a moist meadow & N $50^{\circ} 59^{\prime}$ & E $23^{\circ} 11^{\prime}$ & 29 & $\mathrm{P}, \mathrm{C}$ \\
\hline 33 & Wręborzyce, in a moist meadow & $\mathrm{N} 51^{\circ} 14^{\prime}$ & E $22^{\circ} 34^{\prime}$ & 30 & $\mathrm{P}, \mathrm{C}$ \\
\hline 34 & Suchedniów, in a moist meadow & $\mathrm{N} 51^{\circ} 03^{\prime}$ & E $20^{\circ} 50^{\prime}$ & 29 & $\mathrm{P}$ \\
\hline 35 & Gielniów, in a moist meadow & $\mathrm{N} 51^{\circ} 24^{\prime}$ & E $20^{\circ} 28^{\prime}$ & 30 & $\mathrm{P}$ \\
\hline 36 & Kłocko, in a ditch (in water) & N $51^{\circ} 34^{\prime}$ & E $18^{\circ} 43^{\prime}$ & 30 & $\mathrm{P}$ \\
\hline 37 & Konin, in a moist meadow & $\mathrm{N} 52^{\circ} 13^{\prime}$ & E $18^{\circ} 16^{\prime}$ & 30 & $\mathrm{P}$ \\
\hline 38 & Witaszyce, in a moist meadow & N $51^{\circ} 57^{\prime}$ & E $17^{\circ} 35^{\prime}$ & 30 & $\mathrm{P}$ \\
\hline 39 & Oborniki, in a moist meadow & $\mathrm{N} 52^{\circ} 39^{\prime}$ & E $16^{\circ} 45^{\prime}$ & 30 & $\mathrm{P}$ \\
\hline 40 & Słońsk, in a moist meadow & N $52^{\circ} 33^{\prime}$ & E $14^{\circ} 47^{\prime}$ & 30 & $\mathrm{P}$ \\
\hline 41 & Radnica, in a moist meadow & $\mathrm{N} 52^{\circ} 05^{\prime}$ & E $15^{\circ} 15^{\prime}$ & 28 & $\mathrm{P}$ \\
\hline 42 & Tuchola Żarska, in a ditch (in water) & N $51^{\circ} 48^{\prime}$ & E $15^{\circ} 06^{\prime}$ & 30 & $\mathrm{P}$ \\
\hline 43 & Włostowice, in a moist meadow & N $51^{\circ} 34^{\prime}$ & E $14^{\circ} 51^{\prime}$ & 30 & $\mathrm{P}$ \\
\hline 44 & Bogatynia, in a moist meadow & $\mathrm{N} 50^{\circ} 54^{\prime}$ & E $14^{\circ} 57^{\prime}$ & 25 & $\mathrm{P}$ \\
\hline 45 & Kruszyn, in a moist meadow near a forest & $\mathrm{N} 51^{\circ} 16^{\prime}$ & E $15^{\circ} 34^{\prime}$ & 30 & $\mathrm{P}$ \\
\hline 46 & Kąty Wrocławskie, in a moist meadow & $\mathrm{N} 51^{\circ} 02^{\prime}$ & E $16^{\circ} 46^{\prime}$ & 24 & $\mathrm{P}$ \\
\hline 47 & Domaszów, in a moist meadow and in an alder forest & N $50^{\circ} 52^{\prime}$ & E $16^{\circ} 48^{\prime}$ & 28 & $\mathrm{P}$ \\
\hline 48 & Orłowiec, in a moist meadow & $\mathrm{N} 50^{\circ} 24^{\prime}$ & E $16^{\circ} 51^{\prime}$ & 30 & $\mathrm{P}$ \\
\hline 49 & Niemil, in a moist meadow & N $50^{\circ} 52^{\prime}$ & E $17^{\circ} 16^{\prime}$ & 30 & $\mathrm{P}$ \\
\hline 50 & Jasienica Dolna, in a moist meadow & $\mathrm{N} 50^{\circ} 31^{\prime}$ & E $17^{\circ} 30^{\prime}$ & 30 & $\mathrm{P}$ \\
\hline 51 & Dalachów, in a moist meadow & $\mathrm{N} 51^{\circ} 05^{\prime}$ & E $18^{\circ} 36^{\prime}$ & 29 & $\mathrm{P}, \mathrm{R}$ \\
\hline 52 & Lipie Śląskie, in a ditch (in water) & $\mathrm{N} 51^{\circ} 01^{\prime}$ & E $18^{\circ} 48^{\prime}$ & 25 & $\mathrm{P}$ \\
\hline 53 & Celiny, in a ditch & $\mathrm{N} 50^{\circ} 28^{\prime}$ & E $19^{\circ} 14^{\prime}$ & 28 & $\mathrm{R}$ \\
\hline 54 & Olkusz, in a moist meadow & N $50^{\circ} 17^{\prime}$ & E $19^{\circ} 04^{\prime}$ & 30 & $\mathrm{P}$ \\
\hline 55 & Jejkowice, in a moist meadow & $\mathrm{N} 50^{\circ} 06^{\prime}$ & E $18^{\circ} 27^{\prime}$ & 30 & $\mathrm{P}$ \\
\hline 56 & Jaksice, in a moist meadow & N $50^{\circ} 09^{\prime}$ & E $20^{\circ} 29^{\prime}$ & 25 & $\mathrm{P}$ \\
\hline 57 & Szydłów, in a moist meadow & N $50^{\circ} 36^{\prime}$ & E $21^{\circ} 00^{\prime}$ & 28 & $\mathrm{P}$ \\
\hline 58 & Ruszcza, in a moist meadow & N $50^{\circ} 25^{\prime}$ & E $21^{\circ} 15^{\prime}$ & 30 & $\mathrm{P}$ \\
\hline 59 & Sandomierz, in a moist meadow & N $50^{\circ} 42^{\prime}$ & E $21^{\circ} 45^{\prime}$ & 28 & $\mathrm{P}$ \\
\hline 60 & Ropczyce, in an alder forest & $\mathrm{N} 50^{\circ} 02^{\prime}$ & E $21^{\circ} 36^{\prime}$ & 30 & $\mathrm{R}$ \\
\hline 61 & Susiec, in a moist meadow & $\mathrm{N} 50^{\circ} 25^{\prime}$ & E $23^{\circ} 12^{\prime}$ & 30 & $\mathrm{P}, \mathrm{C}$ \\
\hline 62 & Krówniki, in a ditch, in water & N $49^{\circ} 46^{\prime}$ & E $22^{\circ} 52^{\prime}$ & 28 & $\mathrm{P}$ \\
\hline 63 & Raba Niżna, in a moist meadow & $\mathrm{N} 49^{\circ} 38^{\prime}$ & E $20^{\circ} 01^{\prime}$ & 30 & $\mathrm{~L}$ \\
\hline 64 & Babia Góra, at a stream & $\mathrm{N} 49^{\circ} 35^{\prime}$ & E $19^{\circ} 32$, & 28 & $\mathrm{~L}$ \\
\hline 65 & Ustroń, in a stream & $\mathrm{N} 49^{\circ} 44^{\prime}$ & E $18^{\circ} 48^{\prime}$ & 30 & $\mathrm{~L}$ \\
\hline 66 & Tatry Mts, Dolina Pańszczycy valley, at a stream, 1685 m a.s.l & $\mathrm{N} 49^{\circ} 15^{\prime}$ & E $20^{\circ} 03^{\prime}$ & 30 & $\mathrm{~L}$ \\
\hline 67 & Tatry Mts, Dolina Pięciu Stawów Polskich valley, in a swamp, 1870 m a.s.l. & $\mathrm{N} 49^{\circ} 13^{\prime}$ & E $20^{\circ} 02^{\prime}$ & 34 & $\mathrm{~L}$ \\
\hline 68 & Tatry Mts, Dolina Rybiego Potoku valley, at a stream, 1370 m a.s.l & $\mathrm{N} 49^{\circ} 13^{\prime}$ & E $20^{\circ} 05^{\prime}$ & 21 & $\mathrm{~L}$ \\
\hline 69 & Muszyna, in a ditch & $\mathrm{N} 49^{\circ} 21^{\prime}$ & E $20^{\circ} 55^{\prime}$ & 30 & $\mathrm{~L}$ \\
\hline 70 & Tarnawa Niżna, in a moist meadow & $\mathrm{N} 49^{\circ} 07^{\prime}$ & E $22^{\circ} 48^{\prime}$ & 30 & $\mathrm{~L}$ \\
\hline 71 & Bieszczady Mts, Halicz, at a stream & $\mathrm{N} 49^{\circ} 05^{\prime}$ & Е $22^{\circ} 46^{\prime}$ & 42 & $\mathrm{~L}$ \\
\hline
\end{tabular}


TABLE 2. Nine quantitative characters within respective taxa of the $C$. palustris L. complex. For abbreviations of characters see Table 3 . X - arithmetical mean; SD - standard deviation; SE - standard error; Min - minimum value; Max - maximum value.

\begin{tabular}{|c|c|c|c|c|c|c|c|c|c|c|c|c|c|c|c|c|c|c|c|c|}
\hline & \multirow{2}{*}{\multicolumn{5}{|c|}{ C. laeta }} & \multicolumn{15}{|c|}{ C.palustris } \\
\hline & & & & & & \multicolumn{5}{|c|}{ subsp. palustris } & \multicolumn{5}{|c|}{ subsp. radicans } & \multicolumn{5}{|c|}{ subsp. cornuta } \\
\hline $\begin{array}{l}\text { Number } \\
\text { of individuals }\end{array}$ & \multicolumn{5}{|c|}{305} & \multicolumn{5}{|c|}{1242} & \multicolumn{5}{|c|}{442} & \multicolumn{5}{|c|}{68} \\
\hline Characters & $\mathrm{X}$ & SD & SE & Min & Max & $\mathrm{X}$ & SD & SE & Min & Max & $\mathrm{X}$ & SD & SE & Min & Max & $\mathrm{X}$ & SD & SE & Min & Max \\
\hline $\mathrm{AF}$ & 19.02 & 7.95 & 0.44 & 4.12 & 44.75 & 19.63 & 10.97 & 0.31 & 1.80 & 69.06 & 26.53 & 12.54 & 0.60 & 2.20 & 61.5 & 35.54 & 11.55 & 1.49 & 11.26 & 74.34 \\
\hline AS & 48.25 & 28.75 & 1.46 & -17.50 & 152.5 & 40.56 & 26.89 & 0.75 & -60.0 & 128.5 & 50.91 & 29.12 & 1.39 & -45.00 & 142.5 & 57.64 & 32.21 & 4.16 & -15.00 & 150.0 \\
\hline $\mathrm{RF}$ & 0.88 & 0.03 & 0.00 & 0.77 & 0.94 & 0.88 & 0.05 & 0.00 & 0.57 & 0.95 & 0.85 & 0.06 & 0.00 & 0.62 & 0.95 & 0.79 & 0.07 & 0.01 & 0.51 & 0.90 \\
\hline $\mathrm{DD}$ & 1.76 & 0.14 & 0.01 & 1.35 & 2.17 & 1.76 & 0.17 & 0.00 & 1.21 & 4.69 & 1.82 & 0.18 & 0.01 & 1.23 & 2.45 & 1.91 & 0.21 & 0.03 & 1.42 & 2.54 \\
\hline DL & 3.50 & 1.23 & 0.06 & 0.65 & 6.70 & 3.45 & 1.06 & 0.03 & 0.75 & 7.70 & 2.87 & 0.98 & 0.05 & 0.60 & 7.15 & 3.93 & 1.16 & 0.15 & 0.95 & 6.45 \\
\hline WL & 1.77 & 0.14 & 0.01 & 1.42 & 2.51 & 1.78 & 0.18 & 0.01 & 0.94 & 2.50 & 1.81 & 0.19 & 0.01 & 1.29 & 2.83 & 1.82 & 0.22 & 0.03 & 1.41 & 2.40 \\
\hline RL40 & 0.94 & 0.05 & 0.00 & 0.79 & 1.13 & 0.88 & 0.05 & 0.00 & 0.70 & 1.05 & 0.91 & 0.06 & 0.00 & 0.71 & 1.13 & 0.90 & 0.05 & 0.01 & 0.78 & 1.02 \\
\hline RL80 & 0.89 & 0.07 & 0.00 & 0.70 & 1.26 & 0.84 & 0.07 & 0.00 & 0.62 & 1.12 & 0.86 & 0.08 & 0.00 & 0.65 & 1.14 & 0.86 & 0.08 & 0.01 & 0.73 & 1.09 \\
\hline RL140 & 0.55 & 0.26 & 0.01 & 0.00 & 1.11 & 0.71 & 0.25 & 0.01 & 0.00 & 1.20 & 0.62 & 0.30 & 0.01 & 0.00 & 1.13 & 0.63 & 0.31 & 0.04 & 0.00 & 1.01 \\
\hline
\end{tabular}

TABLE 3. The list of quantitative and qualitative characters studied; characters used further in numerical analysis of the C. palustris complex are distinguished by abbreviations in the $1^{\text {st }}$ column.

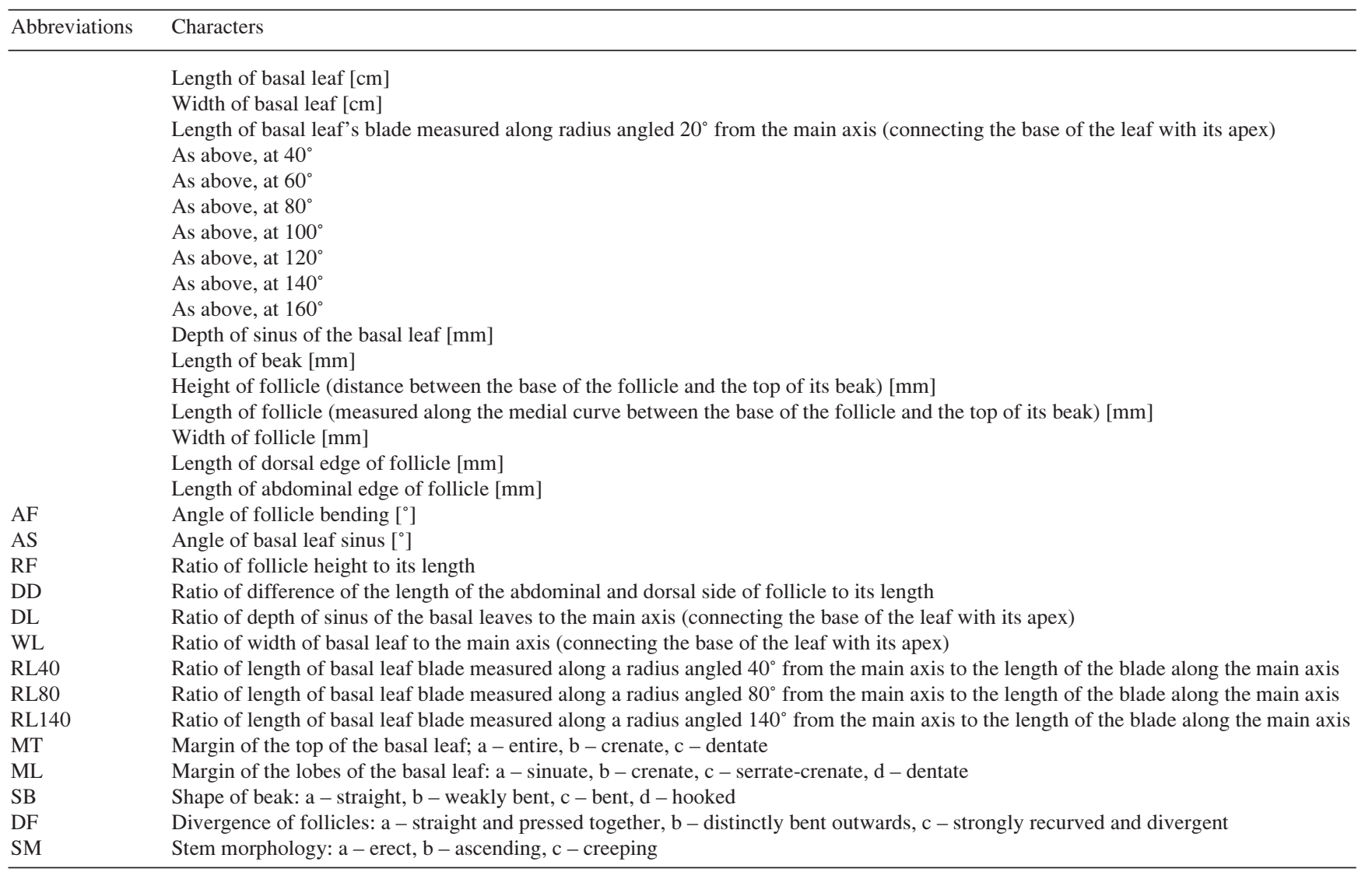

TABLE 4. Values of Wilks' lambda and partial Wilks' lambda for nine quantitative characters - resulting from the Discriminant Analysis (DA) of the individuals of the $C$. palustris $\mathrm{L}$. complex $(\mathrm{p}<0.05)$; $\mathrm{F}$ values for nine quantitative characters - resulting from variance analysis ANOVA, $\mathrm{p}<0.05$ for 4 groups $(\mathrm{df}=3)$ and 2069 individuals $(\mathrm{df}=2075)$. See Table 3 for abbreviations of characters.

\begin{tabular}{cccc}
\hline Characters & Wilks' lambda & partial Wilks' lambda & F \\
\hline AF & 0.59 & 0.99 & 82.03 \\
AS & 0.58 & 0.99 & 23.31 \\
RF & 0.59 & 0.97 & 92.86 \\
DD & 0.58 & 0.99 & 26.38 \\
DL & 0.64 & 0.91 & 42.08 \\
WL & 0.59 & 0.98 & 4.18 \\
RL40 & 0.66 & 0.87 & 130.88 \\
RL80 & 0.58 & 0.99 & 50.83 \\
RL140 & 0.62 & 0.93 & 42.09 \\
\hline
\end{tabular}

and length of the follicle and its bending angle, form and length of beak, form and size of basal leaf blade, angle of sinus of basal leaf, and type of stem growth. The choice of these characters was based on the results of numerical analyses (PCA, CA, DA, and variance analysis).

\section{Characteristics of the morphotypes}

Classification of the analyzed population samples was based on the set of values of quantitative and qualitative characters. In the first step the mean values of the characters for particular populations were the subject to cluster analysis (grouping by k-average method). As a result one can distinguish four well separated and nearly equidistant groups which will be assigned to four morphotypes. Classification of populations to particular groups is shown in Table 1. In the next step, the matrix of the distances between 


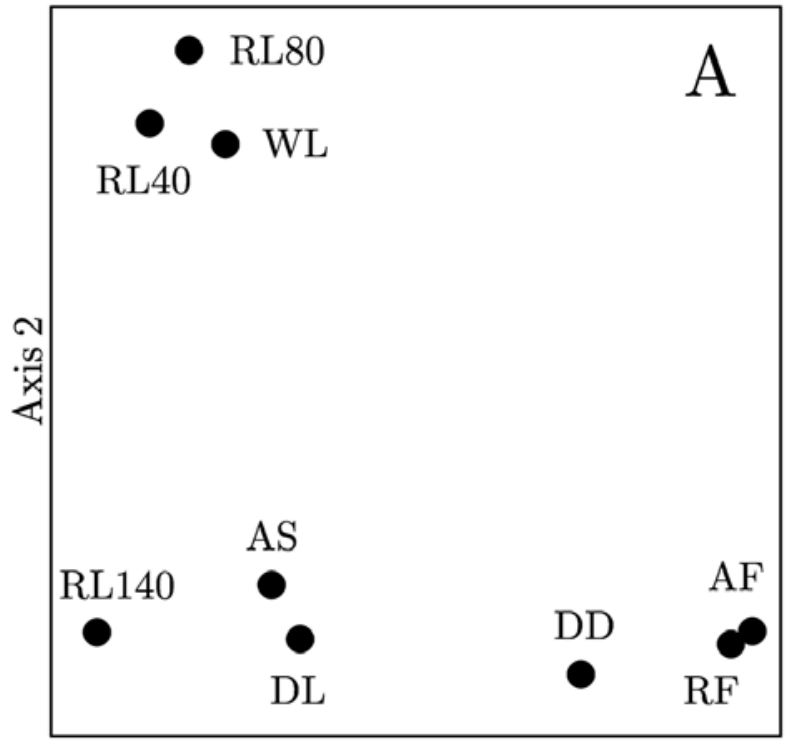

Axis 1

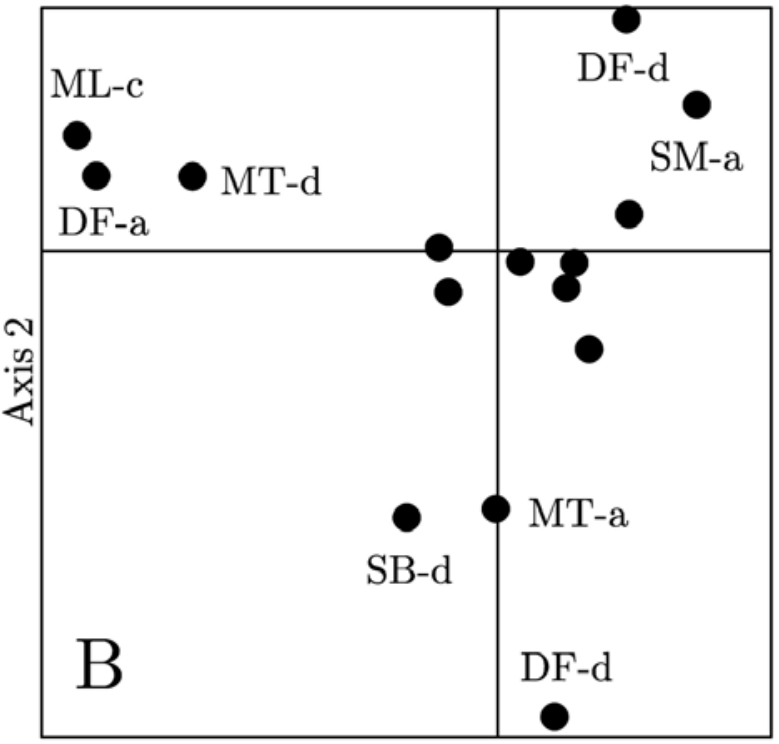

Axis 1

Fig. 1. Morphometric multivariant analysis of the C. palustris complex. A - PCA: scatter of the features against first two axes. B - CA: scatter of the features against first two axes. Abbreviations for features and their states are indicated in Table 3.

groups (Table 5) obtained from this calculations was analyzed according to multidimensional scaling method and the distribution of groups is presented in Fig. 2.

TABLE 5. The matrix of the distances between four ditinguished groups obtained from cluster analysis (grouping by k-average method). The names of taxa are indicated on the basis of later classification.

\begin{tabular}{lcccc}
\hline & C. laeta & $\begin{array}{c}\text { C.palustris } \\
\text { subsp. } \\
\text { palustris }\end{array}$ & $\begin{array}{c}\text { C.palustris } \\
\text { subsp. } \\
\text { cornuta }\end{array}$ & $\begin{array}{c}\text { C.palustris } \\
\text { subsp. } \\
\text { radicans }\end{array}$ \\
\hline $\begin{array}{l}\text { C. laeta } \\
\text { C.palustris } \\
\quad \text { subsp. palustris }\end{array}$ & - & 21 & 19 & 21 \\
$\begin{array}{l}\text { C.palustris } \\
\text { subsp. cornuta }\end{array}$ & 19 & - & 26 & 27 \\
$\begin{array}{l}\text { C.palustris } \\
\text { subsp. radicans }\end{array}$ & 21 & 26 & - & 29 \\
\hline
\end{tabular}

The set of both qualitative and quantitative features was used in DA. The results confirmed the relevancy of choice of all previously selected characters, which allowed the best characterization of the taxa distinguished within the complex. In all four cases the correct classification is near or higher than $90 \%$ (see Table 6).

The differences appearing within the complex, when treating quantitative or qualitative data, can be illustrated by graphs created on the basis of PCA and CA analyses. Because of the great number of individuals taken to this calculations (2075 OTUs) the results presented in a traditional way might be illegible, so they were first averaged in ranges of the particular populations. In 15 cases non-homogeneous populations were found, therefore they were split and individuals were classified into two separate groups (Table 1). Examples of the results for the first two axes, and for both the methods (after averaging) are presented in Fig. 3. Unfortunately, total variability of the complex can be explained only using at least three dimensions for each method, additionally rather low values of explained varia-

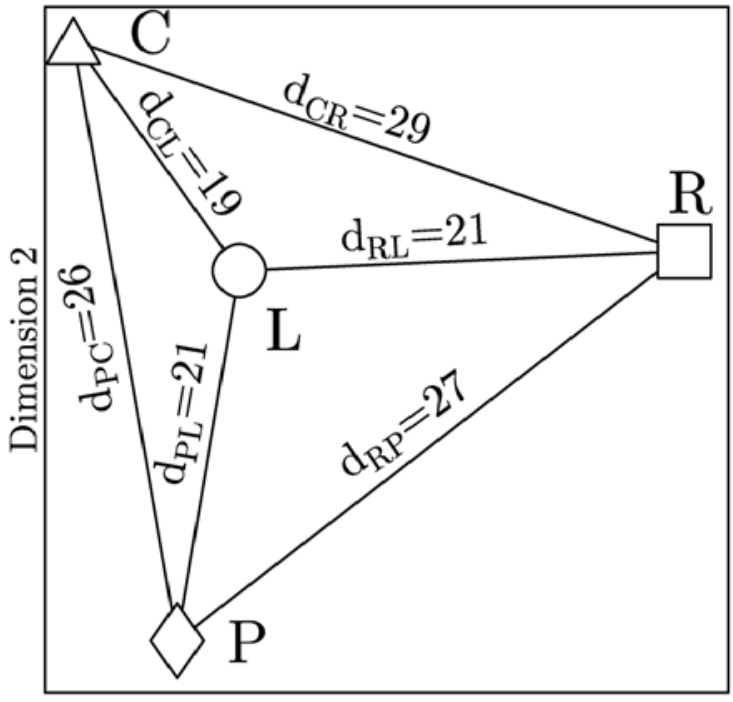

Dimension 1

Fig. 2. Multidimensional scaling picture of Cluster Analysis (k-average grouping) results. The distances between particular groups are indicated. Designations (with respect to the later classification): $\diamond C$. palustris subsp. palustris, $\triangle$ C. palustris subsp. cornuta, $\square$ C. palustris subsp. radicans, $\bigcirc$ C. laeta.

tion in PCA and CA separately are caused by the fact, that two of the groups distinguished earlier are separated mainly on the basis of qualitative features, and the remaining two need both qualitative and quantitative characters (both methods are useful for exclusively quantitative and qualitative features), so the range of explained variability is expected to be relatively lower than for the full set of characters. All this limitations cause, that the distinguished groups are not clearly separated on the particular pictures and analysis of PCA and CA results carried out in that way is difficult. In order to overcome these difficulties, the results of both PCA and CA analyses were the subject of cluster analysis and are presented in form of a dendrogram in Fig. 4. It shows the two main clusters divided into several minor groups. 
TABLE 6. Classification matrix of 2075 individuals to four taxa distinguished within the $C$. palustris L. complex based on the nine quantitative characters - resulting from the Discriminant Analysis (DA).

\begin{tabular}{|c|c|c|c|c|c|}
\hline \multirow[t]{2}{*}{ Actual taxon } & \multirow[t]{2}{*}{$\begin{array}{l}\text { Number of individuals } \\
\text { belonging to the taxon }\end{array}$} & \multicolumn{4}{|c|}{$\begin{array}{c}\text { Predicted taxa membership } \\
\text { (no. of observations and percent properly classified into the resp. taxa) }\end{array}$} \\
\hline & & C. laeta & $\begin{array}{l}\text { C.palustris } \\
\text { subsp. palustris }\end{array}$ & $\begin{array}{l}\text { C. palustris } \\
\text { subsp. cornuta }\end{array}$ & $\begin{array}{l}\text { C.palustris } \\
\text { subsp. radicans }\end{array}$ \\
\hline C. laeta & 305 & $275(90 \%)$ & 29 & 1 & 0 \\
\hline C. palustris subsp. palustris & 1242 & 8 & $1200(97 \%)$ & 34 & 0 \\
\hline C. palustris subsp. cornuta & 68 & 0 & 0 & $68(100 \%)$ & 0 \\
\hline C. palustris subsp. radicans & 442 & 0 & 0 & 0 & $442(100 \%)$ \\
\hline Total & 2057 & 283 & 1229 & 103 & 442 \\
\hline
\end{tabular}

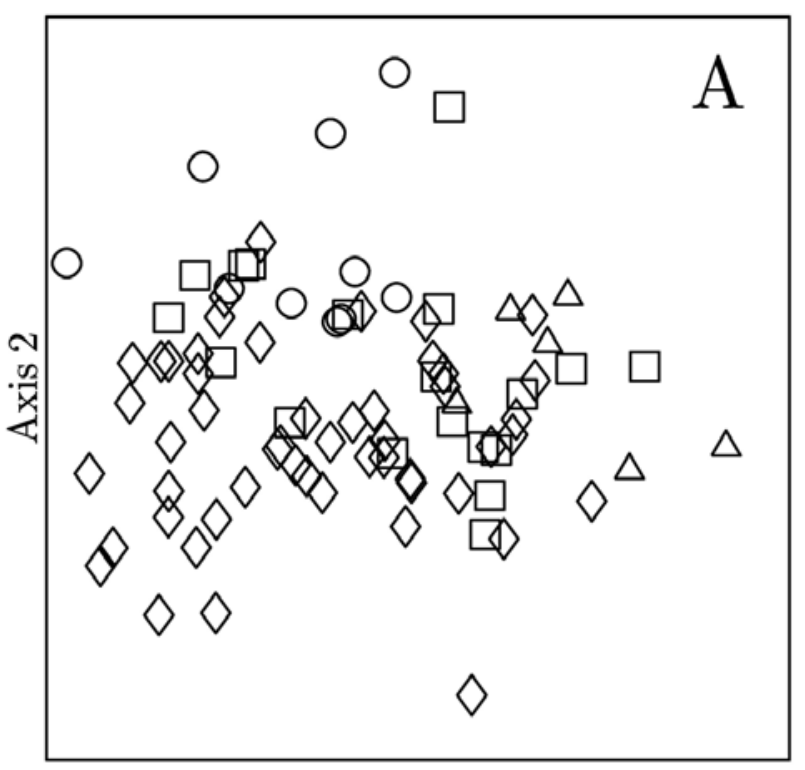

Axis 1

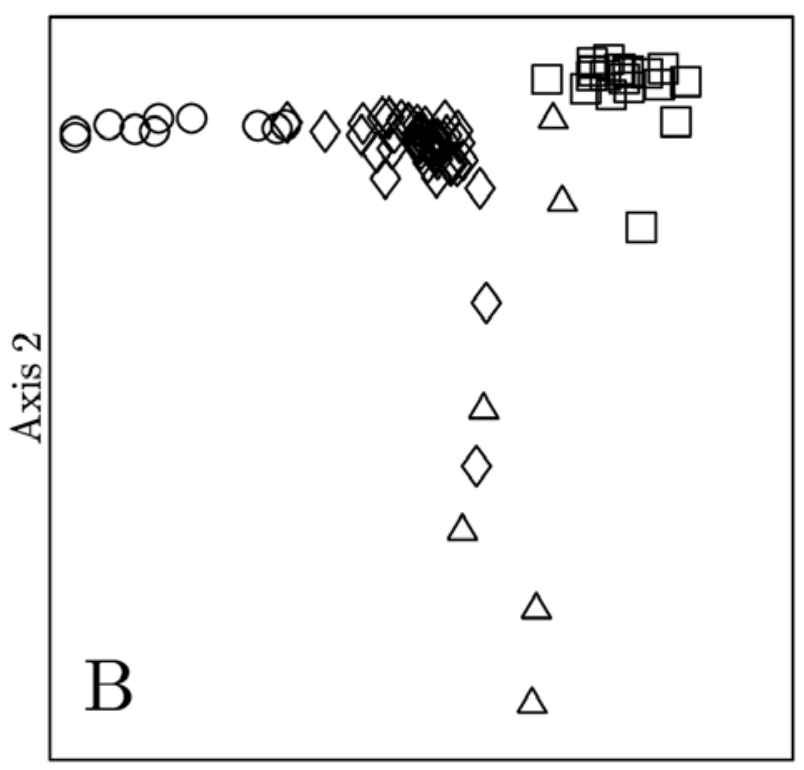

Axis 1

Fig. 3. Morphometric multivariant analysis of the Caltha palustris complex. A - PCA: scatter of the averaged locations (see description in the text) against first two axes. B - CA: scatter of the averaged locations against first two axes. Designations: $\diamond C$. palustris subsp. palustris, $\triangle$ C. palustris subsp. cornuta, $\square$ C. palustris subsp. radicans, $\bigcirc$ C. laeta.

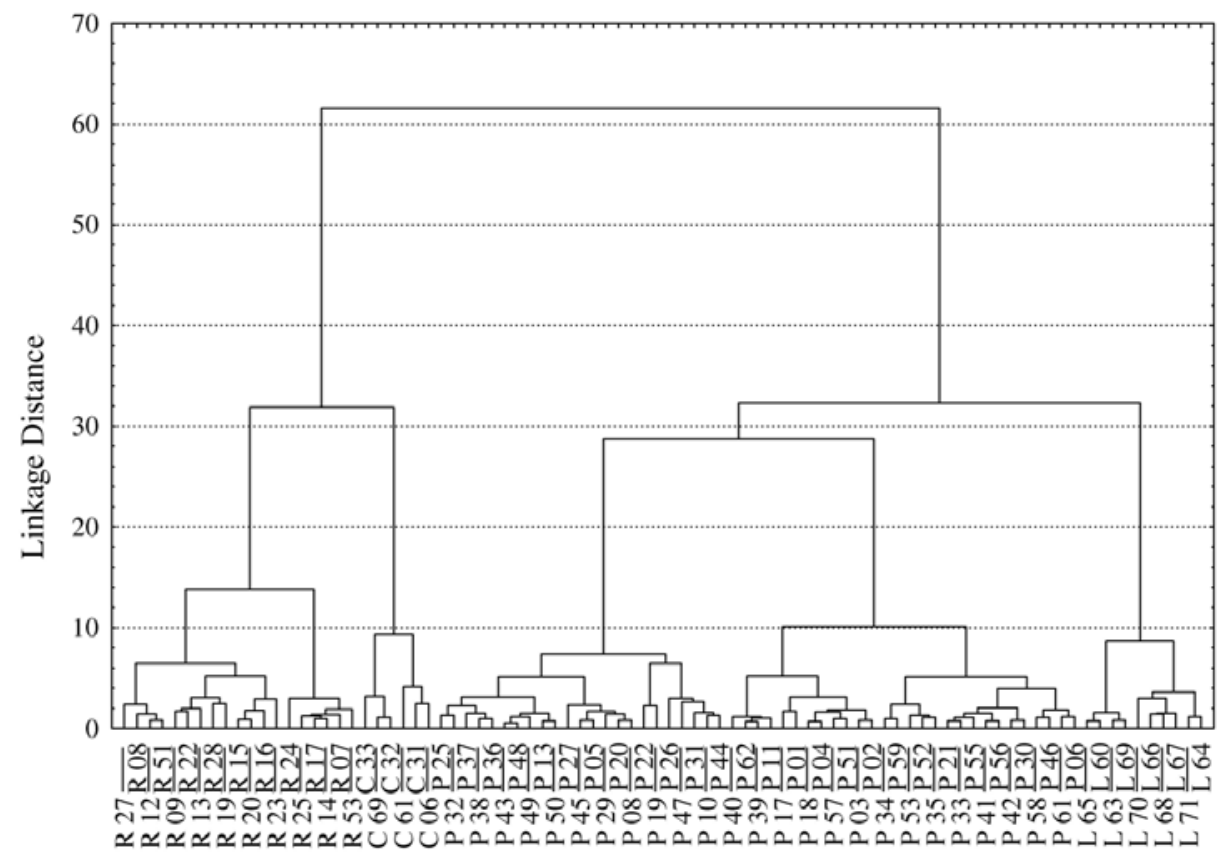

Fig. 4. Cluster Analysis (Ward's method of clasification and City-block distance) depicting relationships among population samples of $C$. palustris complex. Numbers of populations and abbreviations of classification designation sare also indicated: $\mathrm{P}-C$. palustris subsp. palustris, $\mathrm{C}-C$. palustris subsp. cornuta, $\mathrm{R}-C$. palustris subsp. radicans, $\mathrm{L}-$ C. laeta. 
Further analyses were carried out with respect to the geographical distribution of the investigated material. A significant correlation between morphological variability of the samples and their geographical location has been found and strongly confirmed by the high value of correlation coefficient $(\mathrm{r}=0.1215)$ obtained by means of the Mantel test (100 random interactions, out of more than $1 \times 10^{9}$ possible permutations, $\mathrm{p}<0.003)$.

\section{DISCUSSION}

This study of morphological variation of $C$. palustris complex is based on results of statistical analysis of morphological characters, as well as the geographical distribution of the investigated populations from Poland. The latter is based on the results of Mantel test, while the former stems mainly from the cluster analysis of the raw features (Fig. 1) as well as results of PCA and CA (Fig. 4). The right, main cluster in this figure consists of two subclusters: the first one is constituted exclusively by morphotype "laeta". This group is connected only with mountain and submountain areas and it can be identified as the species $C$. $l a$ eta Schott, Nyman and Kotschy (Schott et al. 1854; Paczoski 1927; Pawłowski 1956; Kucowa 1985; Szafer et al. 1953). The second one, constituted by the "palustris" morphotype is split into several subclusters (this is the result of the great variety within this taxon) and can be identified as the species $C$. palustris L. s. str. The separate ranges in Poland for $C$. palustris s. str. and C. laeta were also indicated (Cieślak 2002). The $C$. palustris complex is widely distributed throughout the country. It occurs frequently both in the mountains and in the lowlands. The Linnean definition encompasses also a lowland-mountain species (Mirek 1989; Cieślak 2002).

In spite of the great morphological plasticity of the investigated features (which was confirmed by Smit $(1968,1973)$ on the whole geographical range of the genus Caltha), one can not accept $C$. laeta as a synonym of $C$. palustris (Smith 1973). Based on the results of numerical analysis, taking into consideration the features concerning the shape and largeness of follicles, leaves and stem type, the author showed, that attributing these two taxa the species rank is fully justified - as it was presented by Pawłowski (1956) and Kucowa (1985). All populations classified to C. laeta were found homogenous. In addition, the cytological investigations carried on $C$. palustris complex proved that the lowland and lower mountain region collections were predominantly tetraploid $(2 n=32)$ whereas higher ploidy $(2 n=56-64)$ was found only in plants from higher mountain regions (Wcisło 1967; Chrtková and Jarolimová 1999).

The left main cluster of the dendrogram (Fig. 4) can be also split into two subclusters: the group which is the most distinctly separated by its repent stem can be accounted as C. radicans described from England by Forster (1807). The last, also well-separated group, distinguished mainly by the hooked beaks and strong recurved and divergent follicles, corresponds to C. cornuta (Schott et al. 1854).

The analysis confirmed the occurrence of individuals with repent stem, rooting at nodes, in Poland (mainly in the NE part of the country). In respect to the range of variability for other characters, i.e. form and size of leaves and follicles, the form radicans follows exactly the variability of subsp. palustris. However, they were accounted here as subsp. radicans within $C$. palustris. In this work, the plants with erected stem, but having distinct roots at nodes, were also included in subsp. radicans. Van Steenis (1971) described such individuals as a separate variety araneosa. Smit (1973) considered both taxa as conspecific and interpreted var. araneosa as a synonym of widely defined var. radicans. In other works (Smit 1967; Woodell and Kootin-Sanwu 1971; Hoffman 1999) such individuals were included into var. radicans, yet considered as an intermediate form between plants characterized by erect or repent types of stem growth. According to Smit (1973) and Hoffman (1999), the occurrence of var. radicans is mainly connected with the arctic part of Europe, while numerous intermediate forms (from erect to partly creeping to procumbent), can be found in Siberia; in all these cases, roots at nodes are present. Generally the distribution of these types is more northerly than that of subsp. palustris, not only in Scandinavia, but also globally (Piirainen 2001). The results of the present work show that such intermediate forms can be easily found also in the Central European nemoral zone.

The occurrence of plants characterised by a kidney-shaped leaf blade, divergent "horny" follicles with hooked beaks was confirmed in Poland. They form the right sub-cluster of the second main cluster in Fig. 4. This morphotype was distinguished as subsp. cornuta (Schott, Nyman and Kotschy) Hegi within C. palustris, even though it appears to be only weakly differentiated in the material collected in Poland. Nevertheless, while taking into account the literature data, the northern border of the distribution area of this morphotype can be traced in this territory. Several intermediate forms were noted between this group and subsp. palustris and subsp. radicans. Additionally, in case of subsp. cornuta all localities were not homogenous (in case of subsp. radicans only 9 non-homogenous of all 20 populations were found - compare Table 1). This type of variability can be taken as the type often found at the edge of the distribution area. On the other hand, the proportionally high percentage of correctly classified individuals indicates, that this morphotype clearly and strongly differs from the whole complex in Poland.

Caltha palustris subsp. palustris occurs in the lowlands as well as in the mountains. It was recorded in all mountain groups from the Sudeten Mts in the west to the Bieszczady Mts in the east, at varying altitudinal ranges, depending on the massif (in the Sudeten Mts it reaches approx. 900 $\mathrm{m}$ a.s.1., while in the Polish Carpathians - $1300 \mathrm{~m}$ a.s.1.).

The localities of $C$. palustris subsp. radicans are concentrated mainly in the northern part of the country, from Pomeranian Lakeland to Białowieża Primeval Forest. A few sites were also recorded in Central Poland and Silesian Upland.

The occurrence of $C$. palustris subsp. cornuta is limited to a narrow belt along eastern borders of the country from the Wyżyna Lubelska Upland to the Wysoczyzna Białostocka Upland.

Caltha laeta occurs in the southeastern part of Poland in mountain sites in the Polish Carpathians - usually higher than $700 \mathrm{~m}$ a.s.1., but also descends into the foothills (down to about $300 \mathrm{~m}$ ). Its upper altitudinal limits reach the alpine belt. The taxon has been never recorded in the Karkonosze Mts (the highest range of the Sudeten Mts).

Despite the great morphological variability of $C$. palustris complex in Poland presented here, and has been 
despite of the presence of some intermediate phenotypes (found in contact areas) the two species, i.e. C. laeta and $C$. palustris, are well differentiated morphologically. Moreover, within C. palustris, beside typical subsp. palustris, also subsp. cornuta should be regarded as a distinct taxon. Additionally the node-rooting forms should be recognized as the third subspecies - subsp. radicans.

Apart from the forms mentioned above, the majority of intermediate phenotypes that can be found in field, seem to be only ecotypes and should not be distinguished at any taxonomical level.

\section{TAXONOMY}

Phenetic relationships between OTUs and their classification inferred from numerical analyses (PCA, CA, DA, cluster analysis and analysis of variance) of the Polish material, allowed to determine four frequently occurring groups of morphotypes. Based on these morphotypes, the taxonomy of the complex in Poland was proposed.

Key for determination of species and subspecies of the genus Caltha in Poland

A - Ripe follicles straight and pressed together, abruptly narrowed into a short beak; the beak \pm straight, basal leaves almost orbicular or orbicular, the lobes of basal leaves \pm overlapping, stem \pm erect, not rooting at nodes

Caltha laeta

A' - Ripe follicles slightly or strongly divergent, not rooting at nodes

B - Stem ascending or creeping, rooting at nodes

C. palustris subsp. radicans

B' - Stem erect, not rooting at nodes

C - Ripe follicles weakly bent and slightly divergent, gradually narrowed into a weakly bent beak; basal leaves deltoid to triangular, usually longer than broad

Caltha palustris s. str.

C' - Ripe follicles strongly recurved and divergent, narrowed into a distinctly bent or hooked beak, basal leaves reniform to deltoid, the lobes of basal leaves not overlapping, not rooting at nodes C. palustris subsp. cornuta.

\section{DESCRIPTION OF TAXA}

Caltha palustris L. subsp. palustris L. [Sp. Pl. ed. 1 1: 558 (1753)]

Herbaceous perennial. Roots - stout and numerous. Stem $15-52(81) \mathrm{cm}$, green (sometimes in basal part - red), glabrous, erect or ascending, multi-branched in its upper part, multi-flowered. Basal leaves long-petiolate; cauline leaves shortly petiolate to sessile, dark-green, glabrous, usually longer than broad, cordate, deltoid to triangular in shape; margins of the basal leaves slightly dentate or crenate, sometimes \pm entire at the top and with crenate, dentate or slightly dentate basal lobes. Flowers solitary or in few-flowered cymes; perianth 1-whorled, consisting of 5-10 yellow, petaloid sepals; stamens numerous; carpels 5-15, free, spirally arranged. Fruit: follicles, when ripe, weakly bent and slightly divergent, narrowed into a (weakly) bent beak; seeds numerous, brown.
Caltha palustris subsp. cornuta (Schott, Nyman and Kotschy) Hegi, [Ill. Fl. Mitteleur. 3: 458 (1912)]

Stem 16-50(79) cm, erect, multi-branched, multi-flowered. Basal leaves long-petiolate, deltoid to reniform in shape, usually broader than long, sinus of basal leaves varies between $20^{\circ}$ and $90^{\circ}\left(150^{\circ}\right)$, margins \pm entire at the top and with crenate-dentate basal lobes; lobes usually not overlapping. Fruit: follicles, when ripe, strongly recurved and divergent, gradually narrowed into a bent or hooked beak.

Caltha palustris subsp. radicans (T.F. Forst.) Syme [Engl. Bot. 3 (1): 49 (1863)]

Stem 17-47 (60) cm, ascending, creeping or procumbent, rooting at nodes and with few branches, eventually turning up to produce 1-2 flowers. Basal leaves deltoid to triangular, longer than broad; margins crenate to \pm entire at the top and with crenate-dentate basal lobes usually not overlapping. Fruit: follicles, when ripe, \pm slightly divergent, with a (weakly) bent beak, often with not numerous seeds.

Caltha laeta Schott, Nyman and Kotschy [Analecta botanica 33 (1854)]

Stem 13-58 (80) cm, erect, with few branches, producing 1-3 flowers; Basal leaves long-petiolate, almost orbicular or orbicular in shape, as long as broad; margins of basal leaves crenate-dentate at the top and with basal lobes distinctly dentate, crenate or toothed, \pm overlapping. Flowers solitary or in few-flowered cymes; perianth 1-whorled, consisting of 5-10 yellow petaloid sepals; stamens numerous; carpels 5-15, free, spirally arranged. Fruit: follicles, when ripe, upright and pressed together, abruptly narrowed into the short and \pm straight beak.

\section{ACKNOWLEDGEMENTS}

I would like to thank prof. Zbigniew Mirek and the anonymous Referee for their constructive comments, valuable advice and suggestions for this paper.

This research was supported by the State Committee for Scientific Research (KBN) grant no. 6P04C 05113.

\section{LITERATURE CITED}

AKEROYD J.R. 1993. Caltha L. In: Tutin T.G., Burges N.A. Chater A.O., Edmondson J.R., Heywood V.H., Moore D.M., Valentine D.H., Walters S., Webb D.A. (eds). Flora Europaea. Ed. 2, Univ. Press, Cambridge, 1: 81.

BECK G. 1886. Versuch einer Gliederung des Formenkreises der Caltha palustris. Verh. Zool.-Bot. Ges. Wien 36: 347-352.

CHRTKOVÁ A., JAROLIMOVÁ V. 1999. Cytotaxonomical study of Caltha palustris. Preslia 71: 349-360.

CIEŚLAK E., ILNICKI T., FLIS M. 2000. Cytotaxonomical studies on the Caltha palustris complex (Ranunculaceae) in Poland. Preliminary report. Acta Biol. Cracov. Ser. Bot. 42(1): 121-129.

CIEŚLAK E. 2002. Rozmieszczenie rodzaju Caltha L. w Polsce. [Distribution of the genus Caltha L. in Poland]. Fragm. Flor. Geobot. Ser. Pol. 9: 122-160 (in Polish).

FALIŃSKA K. 1974. Reakcje populacji roślinnych na zróżnicowanie ekosystemów oraz układów ekotonowych [Reaction of plant populations to differences in ecosystems and ecotone systems]. Wiad. Ekol. 20(4): 356-376 (in Polish with English summary). 
FALIŃSKA K. 1976. Dynamika sezonowa Caltha palustris L. w zbiorowiskach leśnych i łąkowych [Seasonal dynamics of Caltha palustris L. in forest and meadow communities]. Fragm. Flor. Geobot. 22(4): 529-544 (in Polish with English summary).

FALIŃSKA K. 1981. Variability of Caltha palustris L. populations in garden culture. Acta Soc. Bot. Pol. 50: 493-513.

FALIŃSKA K. 1998. Plant population biology. W. Szafer Institute of Botany, Polish Academy of Sciences, Kraków, pp. 58-65.

FORSTER T.F. 1807. Account of a new British species of Caltha. Trans. Linn. Soc. 8: 324.

FRIES E. 1846. Summa vegetabilium Scandinaviae. A. Bonnier. Holmiae \& Lipsiae, pp. IX + 572.

GRAEBNER P. 1929. Caltha. In: Ascherson P. and Graebner P. Synopsis der Mitteleuropäischen Flora, 5(2): 567.

HEGI G. 1912. Caltha L. In: G. Hegi (ed.), Illustrierte Flora von Mittel-Europa, Band 3, Carl Hanser Verlag, München, pp. 458.

HOFFMANN M.H. 1999. Biogeographical and evolutionary patterns in Caltha L. (Ranunculaceae). Bot. Jahrb. Syst. 121: 403-421 .

HROUDA L. 2002. Caltha. In: Kubát K., Hrouda L., Chrtek J. jun., Kaplan Z., Kirschner J. \& Štěpánek J. (eds.). Klíč ke květeně České republiky. [Key to the Flora of the Czech Republic.]. Academia, Praha, pp. 109-110 (in Czech).

HULTĖN E. 1970. The circumpolar plants. II. Dicotyledons. Almqvist \& Wiksell, Stokholm.

HULTÈN E., FRIES M. 1986. Atlas of North European vascular plants. I. Koetz Scientific Books, Königstein, pp. 968.

KUCOWA I. 1985. Caltha L. In: Jasiewicz A. (ed.), Flora Polski. Rośliny naczyniowe [Flora of Poland. Vascular plants], PWN, Warszawa-Kraków, 4: 12-15 (in Polish).

LINNAEUS C. 1753. Caltha. In: Linnaeus C., Species plantarum 1.p. 558.

MIREK Z. 1989. Zasięgi wysokościowe roślin naczyniowych w Karpatach i ich klasyfikacja [Altitudinal ranges of vascular plants in the Carpathians and their classification]. Wiad. Bot. 33(2): 57-64 (in Polish).

MIREK Z., PIĘKOŚ-MIRKOWA H., ZAJĄC A., ZAJĄC M. 1995. Vascular plants of Poland. A checklist. Polish Bot. Stud. Guideb. Ser. 15.

MEUSEL H., JÄGER E., WEINERT E. 1965. Vergleichende Chorologie der zentraleuropäischen Flora. Text pp. 485, Karten pp. 155. VEB G. Fischer Verlag, Jena.

PACZOSKI J. 1927. Caltha L. In: Szafer W. (ed.), Flora polska. Rośliny naczyniowe Polski i ziem ościennych. [Polish Flora. Vascular plants of Poland and adjacent territories], Polska Akademia Umiejętności, Kraków, 3: 9-10 (in Polish).

PAWŁOWSKI B. 1956. Flora Tatrorum. Plantae vasculares. PWN, Warszawa, 1: 269-271 (in Polish).

PIIRAINEN M. 2001. Caltha L. In: Bengt Jonsell (ed.), Flora Nordica. Vol. 2, The Bergius Foundation RSAS, Stockholm, pp. 328-331.
PURSH F. 1813. Flora Americae Septentrionalis. London, 2.

SCHOTT H., NYMAN C.F., KOTSCHY T.H. 1854. Analecta Botanica. Vindobonae.

SKALIŃSKA M., CZAPIK R., PIOTROWICZ M. 1959. Further studies in chromosome numbers of Polish Angiosperms (Dicotyledons). Acta Soc. Bot. Pol. 28: 488-489.

SMIT P.G. 1967. Taxonomical and ecological studies in Caltha palustris L. Proc. Roy. Neth. Acad. Sci. Ser. C 70: 500-510.

SMIT P.G. 1968. Taxonomical and ecological studies in Caltha palustris L. II. Mededl. Bot. Mus. Herb. Rijksuniv. Utrecht 300: 280-292.

SMIT P.G. 1973. A revision of Caltha (Ranunculaceae). Blumea 21: $119-150$.

SOÓ R., KOVÁCS-LÁNG E. 1964. Über einige Formenkreise der Ungarischen und Karpatischen Flora II. Caltha. Annal. Univ. Scient. Budapest. Sectio Biol. 8: 337-344.

STATISTICA PL. 1997 for Windows 5.1. StatSoft, Inc.

STEENIS C.G.G.J. VAN 1971. De zoetwatergetijde-dotter van Biesbosch en de Oude Maas: Caltha palustris L. var. araneo$s a$, var. nov. Gorteria 5: 213-219.

STOHR G. 2002. Caltha. In: Exkursionsflora von Deutschland. 4. Gefässpflanzen: Kritischer Band. Rothmaler W., Jäger E.J., Werner K. (eds). Spektrum Akademischer Verlag, Heidelberg, Berlin, p. 148.

SZAFER W., KULCZYŃSKI S., PAWŁOWSKI B. 1953. Rośliny polskie. [Polish plants] PWN, Warszawa, pp. 11120 (in Polish).

SYME J.T. 1863. In: Sowerby, English botany. Ed. 3(B) 1: 49.

TUTIN T.G. 1964. Caltha. In: Tutin T.G., Heywood V.H., Burges N.B., Valentine D.H., Walters S.M., Webb D.A. (eds), Flora Europea 1, Univ. Press, Cambridge, p. 211.

WCISŁO H. 1964. Experimental hybrids in the genus Caltha L. Acta Biol. Cracov. Ser. Bot. 7: 185-189.

WCISŁO H. 1967. Karyological studies in Caltha palustris L. s.l. Acta Biol. Cracov. Ser. Bot. 10: 1-23.

WCISŁO H. 1968. Further studies on experimental hybrids in Caltha palustris L. s.l. Acta Biol. Cracov. Ser. Bot. 11: 87-103.

WERPACHOWSKI C. 1989. Reproductive strategies of Caltha palustris L. under various living conditions. Acta Soc. Bot. Pol. 58(3): 423-427.

WERPACHOWSKI C. 1998. Caltha palustris populations under conditions of flooded river valley. In: Falińska K. (ed.), Plant population biology, W. Szafer Institute of Botany, Polish Academy of Sciences, Kraków, pp. 114-119.

WOODELL S.R.J., KOOTIN-SANWU M. 1971. Intraspecific variation in Caltha palustris. New Phytol. 70: 173-186.

ZIMMERMANN W. 1965. Familie Ranunculáceae. In: Hegi G. (ed.), Illustrierte Flora von Mittel-Europa, Band 3, Carl Hanser Verlag, München, pp. 78-79.

ZAPAŁOWICZ H. 1908. Conspectus florae Galiciae criticus. Akademia Umiejętności, Kraków, 2, pp. 1-311 (in Polish). 